This work is licensed under a Creative Commons Attribution 4.0 International License.

Ovaj rad dostupan je za upotrebu pod međunarodnom licencom Creative Commons Attribution 4.0.

https://doi.org/10.31820/f.31.1.1

Ranko Matasović

\title{
GENDER RESOLUTION IN CROATIAN, SLAVIC AND PROTO-INDO-EUROPEAN
}

Ranko Matasović, PhD, University of Zagreb and Croatian Academy of Sciences and Arts, rmatasov@ffzg.hr, Zagreb

pregledni članak

UDK 811.163.42’366.52

811.16 '366.52

811.1/.2’366.52

rukopis primljen: 31. prosinca 2018.; prihvaćen za tisak: 18. travnja 2019.

This paper deals with the origin and development of the gender resolution rule according to which the predicate adjective agrees with the masculine antecedent when there is agreement with a conjunction of subjects at least one of which denotes a male person. Apart from Croatian, such a rule exists (or existed) in the other Slavic languages, as well as in Baltic languages, so it can safely be posited for Proto-Slavic and Proto-Balto-Slavic. We further show that most contemporary and ancient Indo-European languages had such a gender resolution rule. Where such a rule does not exist (as in Germanic languages), there is a plausible historical explanation. In Hittite, which preserves the most ancient gender system of Indo-European (with only common and neuter genders, and no feminine gender), the default agreement is with the common gender noun. Recent advances in our understanding of the development of gender in Indo-European allow us to show that the rule taking the masculine as the default gender has developed from the rule taking the common gender as default. This is because the morphemes showing gender agreement on adjectives and pronouns of the masculine gender have developed from Early Proto-Indo-European morphemes expressing the common gender.

Key words: gender; Proto-Indo-European; Proto-Slavic; gender resolution; default gender 


\section{Introduction}

As far as we know, Dionysus Thrax was the first grammarian to use the term 'gender'. In his Greek grammar ( ${ }^{\text {nd }}$ century B. C. De re grammatica,

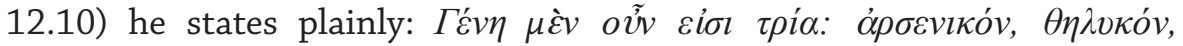

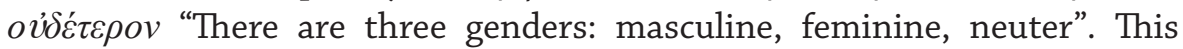
sentence only asserts that Greek, like Croatian, has three genders, but it does not say what gender is. However, a commentary on this passage attributed to Heliodorus (ibid.) defines gender as follows: "Gender is the feature of a word denoting masculine, feminine or neither (of these two) in a vocal expression. The masculine is the gender in front of which, in the nominative singular there is the article ho, the feminine is the one in front of which there is the article $h \bar{e}$, and the neuter (neither) is the one in front of which there is the article to. The definition contains 'in a vocal expression' because philosophers determine the gender on the basis of meaning: they call the masculine that which ejects the sperm, the feminine that which receives the sperm, and the neuter that which does not participate in either. Grammarians, on the other hand, determine gender on the basis of articles". ${ }^{1}$

In this paper, we will follow the grammarians, rather than the "philosophers" (as Heliodorus represents their views on gender) and treat gender as a grammatical category which is revealed by agreement of nominal modifiers with the head noun, or with the predicate with one or more of its arguments (Corbett 1991). ${ }^{2}$ Thus we say that, in Croatian, the noun knjiga 'book' is feminine not because of its meaning, but because it requires feminine forms of adjectives and demonstratives to agree with in the NP:
(1) ova
lijepa
knjiga
this (F.SG) beautiful (F.SG) book (F.SG)
'this beautiful book'

The noun stol 'table', on the other hand, is masculine because it takes masculine agreement:

\footnotetext{
1 My translation.

2 In those Indo-European languages that show gender agreement of the predicate with one of its arguments, this is normally the subject. However, there are also languages in which the predicate agrees in gender with the object (e.g. Swahili and many other Bantu languages).
} 

(2) ovaj
lijepi
stol
this (M.SG) beautiful (M.SG) table (M.SG)
'this beautiful table'

In the same manner, the predicative adjective agrees in gender with the subject:

(3) Knjiga je lijepa

book (F.SG) is beautiful (F.SG)

"The book is beautiful"

(4) Stol je lijep

table (M.SG) is beautiful (M.SG)

"The table is beautiful"

In this paper, we will be concerned with certain constructions in which the usual rules of gender agreement do not, or cannot, apply, e.g. if a masculine and a feminine noun are conjoined. In such a case, there must be a rule stating which form the agreeing adjectives and demonstratives will take, and in Croatian the rule is that it must be the masculine form, as shown by the grammaticality of (5) and the ungrammaticality of (6):

(5) Knjiga istol su lijepi

book and table are beautiful (M.PL)

"The book and the table are beautiful"

(6) * Knjiga istol su lijepe

book and table are beautiful(F.PL)

We will say that such constructions require a "gender resolution rule" and that the agreeing words show the "default" gender (Corbett 1991, Corbett and Fraser 2000), which is, in the example above, the masculine gender. This paper will look at one particular construction in Croatian, Slavic and other Indo-European languages and try to establish its history: we will attempt to establish which default gender can be posited for this construction in Proto-Slavic and in both Early and Late Proto-IndoEuropean. 


\section{2. (Some) gender resolution rules in Croatian}

In Croatian, many constructions that require gender resolution would appear to have the masculine gender as default; we find masculine agreement in constructions with anaphoric pronouns referring to antecedents of mixed gender (7), in constructions with predicative adjectives (8) and participles (9) agreeing with complex NP subjects including conjunctions of nouns of different gender:

(7) Ivan i Marija su došli.

I. and M. AUX.3PL come. PPLE.M.PL

Oni (*One) su moji prijatelji/*prijateljice.

they.M.PL (*they.F.PL) AUX.3.PL my.M.PL friends.M.PL /*friends.F.PL "Ivan and Marija came. They (m.pl/*f.pl) are my friends (m./*f)

(8) Dječaci i djevojčice su dobri/*dobre

boys and girls AUX.3PL good.M.PL/*good.F.PL

"Boys and girls are good (m.pl/*f.pl)"

(9) Dječaci i djevojčice su pjevali/* pjevale.

boys and girls AUX.3PL sing. PPLE.M.PL/*sing.PPLE.F.PL

"Boys and girls sang (m.pl/*f.pl)"

However, masculine is not always the default gender in Croatian (Pišković 2011: 222-224). In some constructions it is the neuter, e.g. when referents of unknown gender are referred to by a neuter form of the numeral jedan 'one' (10), when referents of mixed gender are referred to by the neuter expression njih dvoje 'the two of them' (11), and when the neuter form of the adjective agrees with the infinitive in the subject position (12):

(10) Jedno od supružnika krivo ( ${ }^{*}$ kriva/ ${ }^{*}$ kriv)

one.N of spouses guilty.N.SG $\left({ }^{*} \mathrm{SG} /{ }^{*} \mathrm{M} . \mathrm{SG}\right)$

je za počinjeni zločin.

AUX.3SG for committed crime

"One (n.) of the spouses is guilty $\left(\mathrm{n} . /^{*} \mathrm{f} /{ }^{*} \mathrm{~m}\right)$ of the crime committed" 
(11)

Njih dvoje $\quad$ došlo $\left({ }^{*}\right.$ došla $/{ }^{*}$ došao $)$
of.them two.N come.PPLE.N.SG $\left({ }^{*}\right.$ F.SG $/{ }^{*}$ M.SG $)$

je u petak.

aux.3sg. on friday

"The two of them came $\left(n . /{ }^{*}\right.$ f. $\left./{ }^{*} \mathrm{~m}\right)$ on Friday"

(12) Preskakivati prepone je uzbudljivo ('uzbudljiva/*uzbudljiv)

to.jump hurdles AUX.3SG exciting.N.SG ( ${ }^{*}$ F.SG/* $\left.{ }^{*} \mathrm{M} . \mathrm{SG}\right)$

"It is exciting $\left(\mathrm{n} /{ }^{*} \mathrm{f} . /{ }^{*} \mathrm{~m}\right)$ to jump over hurdles"

These reconstructions will hitherto be ignored. In this paper we will focus only on the construction with nominal predicates, in which the masculine gender is the only choice in Croatian (the type Dječaci i djevojčice su dobri/*dobre, our example 8). ${ }^{3}$

\section{Sexism in grammar?}

We have seen above (example 8) that in the nominal predicate construction the masculine conjunct takes precedence before the feminine conjunct, since the predicative adjective shows masculine agreement. Why does this masculine preference in gender resolution exist? Is it simply a consequence of deep-rooted sexism in the culture of Croatian speakers? Could it be that the "masculine preference" rule is an invention of the grammarians, who were influenced by the dominant, macho-sexist ideology?

Indeed, there is some evidence that rules in normative grammars were sometimes formulated under the influence of gender stereotypes and ideological preconceptions of their authors. For example, Scipion Dupleix, in his "Liberté de la langue françoise dans sa puretée" (1651), writes: Parce que le genre masculin est le plus noble, il prévaut seul contre deux ou plusieurs féminins, quoiqu'ils soient plus proches de leur adjectif "Because the masculine gender is more noble, it prevails by itself over two or more feminines, even

3 This construction is by no means universal. In some languages, e.g. in Tamil (Dravidian), Ungarinjin (Australian) and in several Bantu languages, nouns of different gender cannot be conjoined in a complex NP (Corbett and Fraser 2000). 
if they are closer to their adjective" (pp. 696-7, source: gallica.bnf.fr). A similar passage can be found in Grammaire générale by Nicolas Beauzée (1767): Le masculin est réputé plus noble que le féminin à cause de la supériorité du mâle sur la femelle. "The masculine is reputed to be nobler than the feminine because of the superiority of the male over the female". Such prejudices could be responsible for the "masculine preference" rule, especially if we consider how much the French intellectuals influenced the rest of the Europe in the $17^{\text {th }}$ and the $18^{\text {th }}$ century, especially with their views on language (Matasović 2016). ${ }^{4}$ The very idea that social structure can influence grammar is not as weird as it may appear at first - one only needs to recall the complex honorific systems in languages spoken by highly stratified societies of SE Asia (Matasović 2001: 134). Moreover, it has been suggested that there is a negative correlation between the status of women in society and the "markedness of the feminine" (Alpher 1987). Alpher noted that in some Australian languages, spoken by groups in which women enjoy a better status, the feminine gender tends to be the default (e.g. in Kala Lagaw Ya), while in strongly patriarchal societies the opposite seems to be the case.

However, such a correlation is difficult to ascertain on the global level. In some languages spoken by the groups that treat their women very badly we find that the feminine gender is unmarked, e.g. in Maasai (Nilotic) (13) and Qafar (Cushitic branch of Afro-Asiatic) (14). In comparison to the speakers of Qafar and Maasai, speakers of Romance languages belong to societies with a much higher degree of gender equality, and yet those languages have "masculine preference" rules in gender resolution, as we shall see below.

Qafar (Corbett and Fraser 2000: 77):

(13) gaddàli kinnim yòt celta

wealthy.man be.3SG to.me seem.3SG.F

"He seems to me to be a wealthy man"

4 Apparent sexism in grammar is not necessarily limited to the European languages, nor is it manifested only in spoken language. In Mandarin Chinese, the expression meaning 'parents' is obligatorily written with characters denoting father and mother, but in that particular order. 
Maasai (Motschenbacher 2010: 99):

(14) Aingai na-ewuo?

be.who.SG who.F.SG-come.PF

"Who has come" ("Which woman has come")?

(15) Aingai o-ewuo?

be.who.SG. who.M.SG-come.PF

"Which man has come?"

Note also that feminine as the default gender (at least in some constructions) is not limited to Africa. It is found in many languages and on all continents, e.g. in Oneida (Iroquoian) in North America (Motschenbacher 2010), Mosetén (Mosetenan) in South America (Sakel 2003: 73), etc.

Likewise, the masculine as the default gender is not limited to the Indo-European languages. We find it, e.g., in Hebrew (Givón 2001: 20):

(16) ha-yeled ve-ha-yald-a oxl-im (*oxl-ot)

the-boy(M) and-the-girl(F) eat-M.PL (*eat-F.PL)

"The boy and the girl eat"

So, there does not seem to be a simple and general answer to the questions we asked. A preliminary overview of default agreement in languages distinguishing masculine and feminine genders shows that rules favoring either the masculine or the feminine exist in different language families and on different continents. If we want to know why masculine is the default gender in the Croatian construction discussed above, we cannot rely on language typology or language universals. Rather, we need to turn to language history and prehistory. There is no other way but to look at the constructions requiring gender resolution rules in Slavic and IndoEuropean and try to determine their ultimate source. Only then will we know why this general "masculine preference" and how it came to be. 


\section{Empirical questions should be answered empirically: the history of gender resolution rules in Slavic and Indo-European}

As indicated above, we will limit this investigation to conjuncts containing animate masculine and feminine conjuncts. In constructions with conjuncts belonging to the neuter gender (in languages where the neuter is preserved), as well as in constructions where some conjuncts are inanimate, we find many complex rules for gender resolution (e.g. in Latin, where for inanimate conjuncts the neuter is the default), but these will not be surveyed here.

The questions we shall ask are: 1) is the masculine favoured in all Slavic and Indo-European languages? 2) Which rule(s) can be posited for Proto-Slavic and Proto-Indo-European? 3) How can we explain the origin of these rule(s)?

\subsection{Gender resolution rules in (Balto-)Slavic}

SLOVENE

In Slovene, agreement is with the masculine (Corbett 1991: 280):

(17) Tonček in Marina sta prizadevn-a

T.(M) and M.(F) are.DU assiduous-M.DU

"Tonček and Marina are assiduous"

\section{$\mathrm{CZECH}$}

In Czech, if any of the components is masculine animate, the whole compound is masculine animate plural (http://prirucka.ujc.cas.cz/?id=601):

(18) $K$ dalším pohovorům byli vybráni Jana Jarská a Josef Papeženec.

for further discussions be.3PL.M chosen.M.PL J. J. and J. P.

"Jana Jarská and Josef Papeženec were selected for further discussions"

\section{POLISH}

Polish is similar to Czech; however, in the nominative plural, Polish distinguishes the masculine personal form ending in $-i$ from a general plural ending in $-y$ for masculine non-persons, feminines and neuters. If at least 
one conjunct is masculine personal, then the masculine personal form (ending in -i) is used (Corbett 1991: 284):

(19) Brat, siostry i matka czytal-i

brother sisters and mother read-PF-3PL.M.PERSONAL

"Brother, sisters and mother were reading"

(20) Siostry $i \quad$ matka czytat-y

sisters and mother read-PF-3PL-GENERAL

"Sisters and mother were reading"

\section{RUSSIAN}

In Russian, the three inherited genders have merged in the plural, so plural adjectives have the same form for all genders:

(21) Devuški golodny

girls hungry.PL

"Girls are hungry"

(22) Parni golodny

boys hungry.PL

"Boys are hungry"

(23) Devuški i parni golodny

girls and boys hungry.PL

"Girls and boys are hungry"

The form of the adjective in the Nom. pl. is historically the feminine form. However, this merging is a rather recent development. The form ending in $-y$ co-existed with the form ending in $-i$ (the original masculine form) until the $16^{\text {th }}$ century. By the mid- $16^{\text {th }}$ century, its use was exceptional, e.g. in the "Kniga o ratnom stroe" from 1647: bratija p'jani, gosudari radi. Pushkin has a few instances also: Vzjat' tebja my vse by radi (“Skazka o mertvoj carevne”), Černyx 1962: 203. 


\section{OLD CHURCH SLAVONIC}

There are very few examples in OCS "canonical" texts from which gender resolution rules could be deduced. Večerka (1993: 340) states: In diesem Fall gilt die Regel vom 'Vorrang im Genus', d. $h$. vom Vorrang des Maskulinums vor dem Femininum und dem Neutrum.... "In this case the rule of the prevalence of the masculine gender over the feminine and the neuter applies". He gives a few examples, including the following one:

(24) ašte že bratbilisestra naga budeta $i$

if PCL brother or sister naked.M.DU be.3.DU and

lišena dnevbnaago žitija

deprived.M.DU of. daily accomodation

"if brother or sister are naked and deprived of daily accomodation" (Jak. 2.15):

In (24), naga and lišena are m. dual agreeing with the compound NP bratb ili sestra.

Hence, we have a good case for the conclusion that masculine nouns were favoured as agreement controllers in Proto-Slavic. This is in accordance with the rule we find in Baltic languages, the closest relatives of Slavic languages.

\section{LITHUANIAN (AND LATVIAN)}

In Lithuanian, if one of the conjuncts is masculine, agreement is with the masculine noun (Kristina Okuličiutè Mikac, p. c.):

(25) Berniukai yra geri

"Boys are good (M.PL)"

(26) Mergaitès yra geros

"Girls are good (F.PL)"

(27) Berniukai ir mergaitès yra geri

"Boys and girls are good (M)" 
The same rule obtains in Latvian as well. Thus, Baltic languages agree with Slavic languages and point to the conclusion that the masculine gender was the default in Balto-Slavic for the construction in question.

\subsection{Gender resolution rules in (modern) IE languages}

If we look at the modern IE languages, the masculine preference in gender resolution cannot be stated to be a general rule.

GERMAN

In German, gender distinctions do not exist in the plural; hence, the question of gender resolution does not arise:

(28) Die Jungen sind gut.

"The boys are good"

(29) Die Mädchen sind gut.

"The girls are good"

(30) Die Mädchen und Jungen sind gut.

"The boys and girls are good"

\section{ICELANDIC}

Icelandic does not have masculine preference in gender resolution. The neuter plural is used for any mixture of genders (Corbett 1991: 283):

(31) Drengurinn og telpan eru preytt

boy.M and girl.F are tired.N.PL

"The boy and the girl are tired"

\section{HINDI}

In Hindi, "adjectives and possessive pronouns and verbs usually agree with the closest noun" (Sunil Bhatt, p. c.):

(32) laṛke aur laṛkiyām acchī haị̣

boys and girls good.F are

"The boys and girls are good" 


\section{ALBANIAN}

In Albanian (Ressuli 1985: 205), masculine preference in gender resolution is generally observed:

(33) ime mbesëdhe im birjanëtë_ zgjuar

my.F niece and my.M son are ART.PL.M intelligent

"My niece and my son are intelligent"

(34) pashë t'ët vëlla e t’ët motër shumë të

helmuar

I.saw your.M brother and your.F sister very ART.PL.M sad

"I saw your brother and your sister very sad"

\section{WELSH AND IRISH}

In Modern Welsh, the masculine form of the adjective is used in the predicate even if the subject noun is feminine (Thorne 1993: 133); thus, masculine preference has been taken one step further, as the feminine form cannot be used even if all the conjuncts are feminine. This amounts to saying that there is no gender resolution in Welsh:

(35) Y mae'r gaseg yn gryf

PCL be.3SG.PRES=ART mare(F) PCL strong(M)

"The mare is strong"

(36) Y mae'r gaseg a'r march yn gryfion

"The mare and the horse are strong $(\mathrm{m})$ "

In Irish, the adjectives have a single form in the plural (they do not distinguish gender), and for the largest class of adjectives, this form is originally the feminine/neuter (e.g. móra 'big' is the feminine/neuter form, replacing masculine móir already in the Old Irish period). Hence, the question of gender resolution rules does not arise in Irish.

Thus, if we stick to the modern IE languages, masculine preference is more common, but it is not the only pattern found. However, in ancient IE languages we find exclusively masculine preference in gender resolution. 


\subsection{Gender resolution in ancient IE languages}

\section{LATIN}

In Latin, if conjuncts have the same gender, the agreeing adjective will, of course, agree with it. If they have different genders, however, the masculine takes precedence (Pinkster 2015: 1257):

(37) Mimos dico et mimas, patres conscripti, in agro Campano conlocatos.

"I tell you, members of the Senate, that mime actors and mime actresses have been settled (m.) on Campanian land" (Cic. Phil. 2.101).

\section{GREEK}

In Greek, when substantives denoting persons are of different gender, the masculine agreement prevails (Smyth 1920: 277):

(38) eîde patéra te kaì mētéra kaì adelphoùs kaì tē`n heautoû gynaîka aikhmalốtous gegenēménous, edákryse

"When he saw that his father (m.) and mother (f.) and brothers (m.) and wife (f.) had been made prisoners of war (m.), he burst into tears" (Xen. Cyr. 3.1.7).

\section{SANSKRIT} c.):

In Sanskrit, the agreement is with the masculine (Ivan Andrijanić, p.

(39) pitā mātā ca dvāv (*dve) api

"Father and mother are two (m./*f.)"

For Vedic, Macdonell (1961: 292) hesitantly concludes that the masculine "seems to be preferred". As is often the case with dead languages, there are simply not enough attested examples of this construction:

(40) trayấ vái náirṛtā akșáh stríyah svápnaḥ

"Dice, women and sleep are the treble (m.) pernicious things (m.)". 


\section{OLD NORSE AND GOTHIC}

Ancient Germanic languages are different from the other early IE languages with respect to gender resolution. The neuter preference rule we observed in Icelandic holds in Old Norse as well (Schwink 2008: 92ff.). The same rule is prevalent in Gothic:

(41) wesunuh pan garaihta ba [sc. Zacharias and Elisabeth] in andwairpja gudis, gaggandona in allaim anabusnim jah garaihteim fraujins unwaha

"And they were both (n.) righteous before God, walking (n.) in all the commandments and laws of the lord unblemished (n.)..." (Lk. 1.6)

The rules are apparently the same in Old English, Old High German and Old Saxon (Schwink 2008 92ff.): neuter is the default gender in gender resolution.

However, we know how this situation came about in Germanic: long $*_{\bar{o}}\left(<\right.$ PIE $*_{\text {oh }_{1}}$ ) and long $*_{\bar{a}}\left(<\right.$ PIE $*^{\text {eh }}{ }_{2}$ ) merged in that branch, so the masculine dual ending ${ }^{*}$-o merged with the neuter plural ending ${ }^{*}$-ā. Therefore, the inherited masculine dual in such constructions was reinterpreted as neuter plural. In concrete terms, the endings of nouns in PIE *dwoh wlk $^{\text {woh }}$ 'two wolves' (cf. Gr. Hom. dýo lýkō) and PIE *triyeh $_{2}$ yugeh ${ }_{2}$ 'three yokes' (Gr. tría zygá) now became indistinguishable in ProtoGermanic ('twō wulfō 'two wolves' vs. *briō jukō 'three yokes'). ${ }^{5}$ In adjectives, too, the nominative dual *gupo 'good' became identical to the nominative plural neuter ('gupō), and therefore combining *wulfaz 'wolf' > Goth. wulfs and *kwinōn 'woman' > Goth. qinō in a conjunct subject now triggered the neuter nominative plural / masculine nominative dual form of the predicative adjective, *gupō. After the general loss of the dual in nouns, which happened in Proto-Germanic, this "neuter default" rule was simply generalized as the gender resolution rule for all combinations of subjects of different gender (for both the singular and the plural conjuncts).

Therefore, masculine preference rule seems to be reconstructable for PIE, at least for conjuncts with animate referents. In the single branch

\footnotetext{
5 At a later stage in Proto-Germanic, word-final long *-ō (from PIE ${ }^{*} \bar{o},{ }^{*}$ eh $_{2}$ and ${ }^{*}$ eh ${ }_{3}$ ) was shortened to *-o > *-a, hence the difference between the end-syllables of Goth. qinō 'woman' and Goth. pria 'three' (n.).
} 
where we do not find such a rule (Germanic), there is a convincing explanation why it was replaced by a different rule (agreement with the neuter as the default gender).

\section{Gender Resolution in Early PIE}

If we say that the masculine preference in Croatian is inherited from Proto-Slavic and Proto-Indo-European, this just pushes the need to look for an explanation of this rule further back in time. The question is: how did this rule come into being in PIE?

Early PIE had just two genders (Matasović 2004): common (c.) and neuter (n.). This system is basically preserved in Anatolian (e.g. in Hittite). All neuter nouns referred to inanimates, while common gender nouns referred to animates and some inanimates. We can assume the following resolution rule:

a) if all conjuncts are $c$. the adjective is $c$.

b) if conjuncts are of mixed gender and at least one is animate, the adjective is $c$.

c) otherwise, the adjective is $n$.

This is basically the system we find in Hittite, at least according to the examples in Hoffner and Melchert 2008: 239, e.g.:

(42) dIM-wa LÚ.MEŠ LÚ.KÚR (c.) KUR.KUR.MEŠ LÚ.KÚR (n.) tuk-pat ANA LUGAL ŠAPAL GİR.MEŠ zikkezzi nu-war-uš (c.) arha dannaruš DUG.KAM.HI.A mahhan duwarniškeši

"The storm god puts the enemy men (c.) and the enemy lands (n.) under your feet, o King, and you smash them (c.) like empty vessels" (KBo 15.52 v. 14-17). ${ }^{6}$

The methods of linguistic reconstruction allow us to reconstruct a significant number of PIE nouns with a high degree of certainty and, also, to assign gender to them (Matasović 2004). Thus, we can be certain that

6 Unfortunately, the Hittite corpus does not seem to contain an instance of a complex subject (with nouns of different gender) agreeing with a predicate adjective. However, it is very likely that in such a case the adjective would have been in the common gender form. I do not know of a single language in which the rules of gender resolution for anaphoric pronouns and predicative adjectives do not coincide. 
PIE *mntis 'thought' was a common gender noun since none of its reflexes in individual IE languages are neuter; rather, it was one of the inanimate common gender nouns that became feminine in LPIE, and its reflexes in IE languages are chiefly feminine (Lat. mēns, Skt. matí-, Lith. miñtis, etc.). Likewise, the word for 'woman', * genh $_{2}$ (> Gr. gynế, OCS žena, OIr. ben) was a common gender noun that became feminine by virtue of its meaning, and the word for 'heart' ('k'erd-) was neuter, as evidenced by the gender of Lat. cor, OIr. cride and OCS srbdbce. The agreement patterns for Early PIE may be reconstructed as follows:

*mnteyes senōs $h_{1}$ senti

'the thoughts are old' (c. inanimate)

${ }^{*} g^{w}$ neh ${ }_{2}$ es senōs $h_{1}$ senti

'the women are old' (c. animate)

${ }^{*}$ k'erdeh seneh $_{2} h_{1}$ senti/h $h_{1}$ esti

'the hearts are old' (n.)

The gender resolution rules can be exemplified in the following way:

*mnteyes k'erdeh $-\mathrm{k}^{\mathrm{w}} \mathrm{e} \mathrm{h}_{1}$ senti seneh

"The thoughts (c.) and the hearts (n.) are old (n.)"

${ }^{*} \mathrm{~g}^{\mathrm{w}}$ neh $\mathrm{es} \mathrm{h}_{2}$ nres-kwe $\mathrm{h}_{1}$ senti senōs

"The women (c.) and the men (c.) are old (c.)"

${ }^{*} h_{2}$ nres k'erdeh ${ }_{2} k^{w} e h_{1}$ senti senōs

"The men (c.) and the hearts (n.) are old (c.)"

After the separation of Anatolian, feminine gender developed in the other IE languages. A new agreement pattern (for adjectives) was created for words denoting female humans and animals and a number of inanimates (chiefly abstract nouns which developed from earlier collectives). The new agreement patterns were:

${ }^{*} \mathrm{~g}^{\mathrm{w}}$ neh $\mathrm{h}_{2}$ es $\mathrm{h}_{1}$ senti seneh $\mathrm{es}$

"The women (f.) are old (f.)"

${ }^{*} h_{2}$ nres $h_{1}$ senti senōs

"The men (m.) are old (m.)"

${ }^{*} k^{\prime}$ erdeh ${ }_{2} h_{1}$ senti seneh

"The hearts (n.) are old (n.)" 
However, these changes did not affect the gender resolution rules. Feminines retained the neuter gender resolution rule, when combined with the neuters:

*mnteyes k'erdeh ${ }_{2}-k^{w} e h_{1}$ senti seneh

"The thoughts (f.) and the hearts (n.) are old (n.)"

The fact that we have neuter agreement with inanimate conjuncts of differing genders is probably connected with the fact that neuter nouns and feminines in ${ }^{*}$-eh (including the feminine adjectives in ${ }^{*}$-eh $_{2}$ ) have the same dual ending, differing from the masculine ending (Matasović 2004): the feminine/neuter ending is *-ih (cf. OCS -ě in ženě 'two women', Skt. -e in sene 'two armies (f.)', Gr. -e in ósse 'two eyes (n.)'), and the masculine ending is ${ }^{*}{ }^{-} h_{1}$ (cf. OCS - $a$ in vlrka 'two wolves', Skt. vrrka 'id.'). Consequently, if a neuter and a feminine noun in the singular were conjoined as a subject of a clause with an adjectival predicate, that predicate would be in the feminine/neuter = non-masculine dual. In my opinion, this form was simply the default used in Early PIE for agreement with conjuncts that did not include an animate common gender noun.

The feminines from original animates (common gender nouns) retained the common gender resolution rule; however, in the new gender system, the agreeing form of the adjective (*senōs) was no longer "common", but masculine (its ending was identical to the ending of the masculine 'thematic' stems, e.g. PIE *wlkwōs 'wolves' > Skt. vṛkās): ${ }^{7}$

* $g^{\mathrm{w}}$ neh $\mathrm{h}_{2}$ es $\mathrm{h}_{2}$ nres-kwe $\mathrm{h}_{1}$ senti senōs

"The woman (f.) and the man (m.) are old (m.)"

If animate masculines were combined with inanimates (either old common gender nouns or neuters), the agreement was again with the masculine (since the form that developed from the old common gender ending was retained on the agreeing adjective):

${ }^{*} h_{2}$ nres k'erdeh ${ }_{2} k^{w}$ e $h_{1}$ senti senōs

"The men (m.) and the hearts (n.) are old (m.)"

7 Recall from above that the new feminine Nom. pl. ending for adjectives was ${ }^{*}$-eh 2 es (e.g. *seneh ${ }_{2}$ es f. in opposition to *senōs m.). 
Thus, we arrive at the following gender resolution rules which obtained in (Late) PIE and which were basically retained in the majority of IE languages:

a) If at least one conjunct is masculine and animate, the agreement on the adjective is masculine,

b) otherwise, the agreement is neuter.

\section{Conclusion}

Do we now know why Croatian favours the masculine gender in constructions with predicate adjectives agreeing with conjuncts of different gender? Well, it turns out that this rule (the "masculine preference" rule, as we have called it) is inherited from Proto-Slavic and, in all likelihood, from Proto-Indo-European. We have shown that, in origin, the gender resolution rules (at least for the construction with adjective predicates) probably have nothing to do with sexism, male dominance, or patriarchal social stereotypes. They are simply inherited from the period when PIE had two genders, common and neuter, whereby the old common gender agreement endings remained as masculine endings in the new system, created after the separation of the Anatolian branch.

A completely different question is whether we should change this rule of gender resolution, because it can be seen as sexist or politically incorrect. And, even if we do change it, should it be done by a political decree? Languages change and grammatical rules are subject to change just like everything else in life, but I personally prefer it when the change is spontaneous and not the result of political pressure. To my mind, insisting that the speakers of Croatian (or any other language with "masculine preference" in gender resolution) should use feminine agreement, or randomly feminine and masculine agreement when predicate adjectives agree with conjuncts of different gender, would be like deciding by a political decree that the past tense should no longer be used because the past is reactionary and good citizens should focus on the glorious present and the bright future. Likewise, one day little people could object to the use of capital letters to start a new sentence as discriminating, since it symbolizes that everything that is big or tall should take precedence over things (and people) that happen to be smallish in size. In my opinion, fighting ideological battles on the battlefield of language is counterproductive, since it only shifts attention from the problems certain groups 
face in the real world (like the discrimination of women). I believe that people should be allowed to speak as they wish and be encouraged - but not ordered - to use the standard language with all its imperfections, illogical structures and, if you want, sometimes politically incorrect rules.

\section{References}

Alpher, Barry (1987) "Feminine as the unmarked gender: buffalo girls are no fools”, Australian Journal of Linguistics 7: 169-187.

Chumakina, Marina and Oliver Bond (2016) "Competing controllers and agreement potential", in: Bond, Oliver et al. (eds.) Archi. Complexities of Agreement in Cross-Theoretical Perspective, Oxford: O.U.P., 77-117.

Corbett, Greville (1991) Gender, Cambridge: C.U.P.

Corbett, Greville and Fraser, Norman (2000) "Default Genders", In: Barbara Unterbeck (ed.) Gender in Grammar and Cognition, Part I: Approaches to Gender, Berlin: De Gruyter, 55-98.

Černyx, P. Ja (1962) Istoričeskaja grammatika russkogo jazyka, Moscow: Gosudarstvennoe učebno-pedagogičeskoe izdatel'stvo Ministerstva prosveščenija RSFSR.

Dionizije Tračanin (1995) Gramatičko umijeće (preveo Dubravko Škiljan), Zagreb: Latina et Graeca.

Givón, Talmy (2001) Syntax. An Introduction, Amsterdam: Benjamins. Hoffner, Harry A. and Melchert, H. Craig (2008) A Grammar of the Hittite Language, Pt. I: Reference Grammar, Eisenbrauns: Winona Lake.

Macdonell, A. A. (1961) A Vedic Grammar for Students, Oxford: O. U. P. Matasović, Ranko (2001) Uvod u poredbenu lingvistiku, Zagreb: Matica hrvatska. Matasović, Ranko (2004) Gender in Indo-European, Heidelberg: Winter.

Matasović, Ranko (2014) Slavic Nominal Word-Formation, Heidelberg: Winter. Matasović, Ranko (2016) Lingvistička povijest Europe, Zagreb: Matica hrvatska. Motschenbacher, Heiko (2010) Language, gender and sexual identity. Poststructuralist perspectives, Amsterdam: Benjamins.

Pinkster, Harm (2015) The Oxford Latin Syntax. Vol. 1: The Simple Clause, Oxford: O. U. P.

Pišković, Tatjana (2011) Gramatika roda, Zagreb: Disput.

Ressuli, Namik 1985. Grammatica albanese, Bologna: Patròn Editore. 
Sakel, Jeanette (2003) A Grammar of Mosetén, Ph.D. Thesis, Catholic University of Nijmegen.

Schwink, Frederick W. (2004) The Third Gender. Studies in the Origin and History of Germanic Grammatical Gender, Heidelberg: Winter.

Smyth, Herbert W. (1920) Greek Grammar, Cambridge, MA: Harvard University Press.

Thorne, David A. (1993) A Comprehensive Welsh Grammar, Oxford: Blackwell.

Večerka, Radoslav (1993) Altkirchenslavische (altbulgarische) Syntax. II. Die innere Satzstruktur, Freiburg im Breisgau: U. W. Weiher.

\section{List of abbreviations:}

Croat. $=$ Croatian, Goth. $=$ Gothic, Gr. $=$ Greek, Hitt. $=$ Hittite, Hom. $=$ Homeric, Lat. $=$ Latin, Lith. $=$ Lithuanian, OCS = Old Church Slavonic, OIr. $=$ Old Irish, Russ. $=$ Russian, Skt. $=$ Sanskrit .

\section{List of glosses:}

art $=$ article aux $=$ auxiliary, $\mathrm{du}=$ dual, $\mathrm{f}=$ feminine, $\mathrm{m}=$ masculine, $\mathrm{n}=$ neuter, $\mathrm{pcl}=$ particle, $\mathrm{pf}=$ perfect, $\mathrm{pl}=$ plural, $\mathrm{pple}=$ participle, pres $=$ present, $\mathrm{sg}=$ singular. 


\section{SAŽETAK}

Ranko Matasović

RAZLUČIVANJE RODA U HRVATSKOME, SLAVENSKOME I INDOEUROPSKOME

U ovom se radu raspravlja o podrijetlu i razvitku pravila za razlučivanje roda, po kojemu je predikatni pridjev muškoga roda kad se slaže s više subjekata od kojih barem jedan označava mušku osobu. Osim u hrvatskome, takvo pravilo o zadanoj sročnosti postoji ili je postojalo i u drugim slavenskim jezicima, kao i u baltijskim jezicima, koji su slavenskima genetski najbliži. Nadalje se pokazuje da većina suvremenih i starih indoeuropskih jezika ima isto takvo pravilo o zadanoj sročnosti, a u onima gdje takvo pravilo izostaje (npr. u germanskim jezicima) postoji povijesno objašnjenje za to. U hetitskom jeziku, koji čuva najstarije stanje sustava roda pripisivo ranoindoeuropskome prajeziku (razlikuju se samo opći i srednji rod, a ženskoga roda nema), zadana je sročnost $s$ imenicom općega roda. Na temelju suvremenih spoznaja o razvitku kategorije roda u indoeuropskome pokazuje se da je pravilo o zadanoj sročnosti u muškome rodu nastalo iz pravila o zadanoj sročnosti u općem rodu zbog toga što su nastavci koji pokazuju sročnost na pridjevima i zamjenicama muškoga roda postali od ranoindoeuropskih nastavaka općega roda.

Ključne riječi: rod; praslavenski; indoeuropski prajezik; zadani rod; razlučivanje roda; seksizam u gramatici 